\title{
Kesalahan Calon Guru Matematika dalam Menggunakan Ukuran Pemusatan: Pengabaian Variansi
}

\author{
Kimura Patar Tamba ${ }^{1^{*}}$, Meiva Marthaulina Lestari Siahaan², Oce Datu Appulembang ${ }^{3}$ \\ 1,3Program Studi Pendidikan Matematika, Universitas Pelita Harapan \\ ${ }^{2}$ Program Studi Pendidikan Matematika, Universitas Timor \\ *kimura.tamba@uph.edu
}

\begin{abstract}
Abstrak
Ukuran pemusatan merupakan topik yang sangat penting dalam statistika. Salah satu kemampuan yang harus dikuasai calon guru matematika adalah kemampuan memilih dan menggunakan ukuran pemusatan data. Ketidakmampuan calon guru matematika dalam menggunakan dan memilih ukuran pemusatan data yang sesuai menunjukkan rendahnya pemahaman akan ukuran pemusatan data tersebut. Penelitian ini bertujuan untuk mengeksplorasi sumber kesalahan calon guru matematika dalam menggunakan dan memilih ukuran pemusatan yang tepat dan sesuai. Penelitian ini melibatkan 177 calon guru matematika. Penelitian ini merupakan studi kualitatif dengan menggunakan dengan paradigma interpretif. Data dikumpulkan dengan menggunakan tes berisi dua permasalahan dan wawancara klinis. Data dianalisis secara kualitatif dengan menggunakan mengelompokkan bentuk respon partisipan berdasarkan cara berpikir dan cara memahami dalam menggunakan dan memilih ukuran pemusatan data. Hasil penelitian menunjukkan calon guru matematika tidak dapat memilih ukuran pemusatan yang tepat karena terlalu fokus pada ukuran pemusatan, sembari mengabaikan ukuran variansi. Untuk mampu memilih ukuran pemusatan yang tepat ketika menghadapi permasalahan, variansi harus dipertimbangkan secara bersamaan. Implikasi dari hasil penelitian ini adalah perlunya suatu pendekatan pembelajaran yang memperkenalkan ukuran pemusatan secara bersamaan dengan variansi data.

Kata kunci: rata-rata, median, modus, ukuran pemusatan, variansi
\end{abstract}

\begin{abstract}
The measure of the center is an essential topic in statistics. Pre-service mathematics teachers must have the ability to select and use measures of center. The inability to use and select appropriate center measures indicates a low understanding of center measures. Meanwhile, research on the ability to use and select the center's appropriate measures is very limited. This study explores the sources of error for pre-service mathematics teachers in using and selecting the appropriate measures of center. This study involved 177 pre-service mathematics teachers. This research is a qualitative study using the interpretive paradigm. Data were collected using a test containing two problems and clinical interviews. Data were analyzed qualitatively using grouping participant responses based on ways of thinking and ways of understanding to use and select center measures. The results showed that pre-service mathematics teachers could not select an appropriate measure of centers because they were too focused on measures of centers while ignoring the variance. In order to be able to select an appropriate measure of centers because variance must be considered simultaneously. The implication of this study results is the need for a learning approach that introduces concurrent measures of centers with data variance.
\end{abstract}

Keywords: measures of center, mean, median, mode, variation 


\section{Pendahuluan}

Kemampuan siswa dalam menyelesaikan permasalahan matematis mengenai ukuran pemusatan sangat rendah (Ben-Zvi \& Aridor-Berger, 2015; Koparan, 2015; Morris \& Masnick, 2015; OECD, 2014). Secara khusus mengenai pemilihan ukuran pemusatan yang tepat dalam menyelesaikan permasalahan. Permasalahan mengenai pemilihan ukuran pemusatan yang tepat pernah menjadi topik pada Programme for International Student Assessment (PISA) (OECD, 2014). Hasilnya hanya 30\% siswa yang menjawab dengan tepat. Kondisi ini menuntut suatu studi dan penyelesaian.

Sudah banyak penelitian (misalnya, Amiruzzaman, 2016; Groth \& Bergner, 2006; Ismail \& Chan, 2015; Zawojewski \& Shaughnessy, 2016) yang fokus mendalami ukuran pemusatan. Penelitian-penelitian tersebut mendeskripsikan kesalahan dan kesulitan siswa dalam ukuran pemusatan. Namun pada penelitian tersebut, belum ada yang membahas mengenai pemahaman, kesalahan dan kesulitan dalam konteks memilih ukuran pemusatan yang tepat dalam menyelesaikan masalah.

Memang ada penelitian Holt dan Scariano (2009) mengenai pemilihan ukuran pemusatan yang tepat. Namun penelitian tersebut, lebih menekankan pada usulan mengenai desain didaktis. Padahal untuk mengkonstruksi desain didaktis yang baik, perlu penelitian tentang pemahaman, kesalahan dan kesulitan mengenai topik tersebut. Selain itu, penelitian tersebut masih belum menganalisis calon guru matematika. Artinya, studi akan kemampuan memilih ukuran pemusatan yang tepat untuk konteks tertentu dari calon guru matematika masih sangat terbatas. Padahal kemampuan memilih jenis ukuran pemusatan yang tepat pada suatu permasalahan memberikan gambaran pemahaman seseorang akan ukuran pemusatan (Holt \& Scariano, 2009).

Statistika merupakan studi tentang data, yang sifatnya sangat empiris, kontekstual dan tidak pasti (berubah sesuai dengan konteks). Penalaran statistik, dengan demikian, merupakan penalaran atas data. Data sendiri dapat dilihat sebagai agregat dari nilai-nilai (Konold et al., 2015).

Sejalan dengan itu, statistikawan berpendapat bahwa ciri penting dari suatu kumpulan objek (data) adalah adanya unsur-unsur yang stabil dari sistem yang berubah (variable system) (Konold \& Higgins, 2011; Konold et al., 2015; Konold \& Pollatsek, 2002). Unsur ini menjadi bukti bahwa kumpulan objek (data) yang terpisah tersebut adalah satu kesatuan (agregat) (Konold \& Pollatsek, 2002). Implikasinya, ide sentral sebuah data adalah sebagai suatu agregat (Konold \& Higgins, 2011; Konold et al., 2015; Konold \& Pollatsek, 2002). Ide inilah yang melahirkan konsep ukuran pemusatan. Ukuran pemusatan adalah representasi 
statistik data berbentuk nilai tunggal untuk distribusi dan variansi dari serangkaian objek yang dinyatakan dalam nilai (Manikandan, 2011).

Dengan demikian, ukuran pemusatan merujuk pada nilai stabil (stable value) yang (a) merepresentasikan tanda (the signal) dalam proses yang berubah-ubah (variable proccess) dan (b) pendekatan (aproksimasi) terbaik ketika atas data ketika jumlah observasi bertambah (Ben-Zvi et al., 2012; Braham \& Ben-Zvi, 2017; English \& Watson, 2015; Konold \& Pollatsek, 2002). Oleh karena itu, gagasan ukuran pemusatan tidak dapat dipisahkan dengan ukuran penyebaran. Desain didaktis yang biasa digunakan oleh guru memperkenalkan ukuran pemusatan terpisah dari ukuran penyebaran. Pendekatan seperti ini akan menghasilkan pemahaman dan kesimpulan yang salah. Dalam membanding dua distribusi data atau membuat keputusan, kita harus mempertimbangkan ukuran pemusatan dan penyebaran secara bersamaan: tanda (the signal), dan kebisingan di sekitar tanda (the noise around the signal) ( Konold \& Higgins, 2011; Konold et al., 2015; Konold \& Pollatsek, 2002).

Ada empat jenis ukuran pemusatan yaitu: rata-rata, median, modus dan midrange. Midrange sendiri jarang digunakan bahkan dalam kurikulum 2013 (Indonesia) midrange tidak dicantumkan sebagai ukuran pemusatan (Kemendikbud, 2016). Midrange sering dihindari karena bukan ukuran pemusatan (kecenderungan pemusatan) yang handal. Padahal secara historis semua konsep ukuran pemusatan, khususnya rata-rata, dimulai dari konsep midrange (Bakker, 2003). Tetapi karena dalam dokumen kurikulum 2013 (Indonesia) tidak mencantumkan midrange maka penelitian ini hanya fokus pada rata-rata (mean), median dan modus.

Untuk itu, penelitian ini bertujuan mengeksplorasi dan menginterprerasi pemahaman, kesalahan dan kesulitan calon guru matematika dalam memilih ukuran pemusatan yang tepat. Pertanyaan yang akan dijawab melalui penelitian ini adalah kenapa calon guru matematika tidak dapat memilih ukuran pemusatan yang tepat ketika menyelesaikan suatu permasalahan?

\section{Metode}

Penelitian kualitatif dengan paradigma intepretif digunakan dalam studi ini. Tujuan penggunaan paradigma interpretif adalah untuk memahami pandangan dan interpretasi atas realitas (Cohen et al., 2018) dalam hal ini ukuran pemusatan. Interpretasi partisipan akan ukuran pemusatan akan dilihat dari respons mereka akan permasalahan ukuran pemusatan yang diberikan dan respons mereka atas pertanyaan-pertanyaan dalam wawancara. 
Partisipan adalah calon guru matematika menengah yang telah mendapatkan mata kuliah mengenai statistika. Ada 177 calon guru matematika yang terlibat dalam penelitian ini (laki-laki $=52$, perempuan $=125)$. Latar belakang mereka beragam baik dari sisi suku dan budaya (seperti, Batak, Jawa, Papua, Dayak, Sunda, Ambon, Rote, Alor, Sangir, Toraja). Latar belakang tingkat ekonomi partisipan juga beragam (rata-rata dari ekonomi rendah, namun ada juga yang menengah). Partisipan juga berasal dari lima pulau di Indonesia yaitu pulau Jawa (Banten, Jakarta, Jabar, Jatim, Jateng dan Yogyakarta) = 53, Sumatera (Sumut, Riau, Sumsel dan Lampung) $=71$, Kalimantan (Kaltim, Kalbar, Kalsel $)=8$, Sulawesi dan Maluku $=31$, Papua $=3$ dan Nusa Tenggara Timur $=11$. Nama-nama yang dicantumkan dalam paper ini merupakan nama samaran dari partisipan yang terlibat dalam wawancara.

Dua permasalahan mengenai ukuran pemusatan disebarkan pada setiap partisipan. Dua permasalahan ini disusun untuk mengetahui kemampuan partisipan dalam memilih ukuran pemsuatan yang tepat. Permasalahan pertama melibatkan data yang memiliki nilai pencilan (outliers), sementara permasalahan kedua tidak. Permasalahan ini akan memberikan gambaran cara berpikir (ways of thinking) dan cara memahami (ways of understanding) mengenai ukuran pemusatan data berdasarkan pemilihan ukuran pemusatan yang dilakukan (Blanco \& Chamberlin, 2019; Morris \& Masnick, 2015). Kedua permasalahan tersebut adalah sebagai berikut.

\footnotetext{
Seseorang pegawai Kementerian Ketenagakerjaan diminta untuk melakukan supervisi mengenai besaran gaji karyawan di suatu perusahaan. Pegawai tersebut mengumpulkan data dengan mengambil 10 orang pegawai. Ternyata dalam tingkat pekerjaan yang sama, 10 orang pegawai ini memiliki besar gaji yang berbeda seperti yang ditampilkan dalam tabel berikut.

$\begin{array}{lllllllllll}\text { Karyawan ke- } & 1 & 2 & 3 & 4 & 5 & 6 & 7 & 8 & 9 & 10\end{array}$

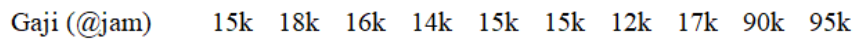

Setelah selesai supervisi, pimpinan menanyakan dikisaran berapa gaji pegawai di perusahaan tersebut. Menurut kamu, apa jawaban seharusnya dari pegawai tersebut dan jelaskan jawabanmu!

2. Dari 5 kali ulangan, Anggi mendapatkan nilai: $80,80,75,76,77$. Jika Guru ingin melaporkan hasil belajar Anggi pada orang tuanya dengan menyebutkan satu angka yang mewakili kelima ulangan tersebut, berapa yang akan disebutkan oleh guru. Jelaskan!
}

Gambar 1. Permasalahan yang diberikan

Analisis data dilakukan dengan mengelompokkan respon calon guru matematika berdasarkan ketepatan dalam memilih ukuran pemusatan yang sesuai. Dari kedua kelompok ini kemudian dilakukan analisis atas alasan yang digunakan. Berdasarkan analisis ini, alasan pemilihan ukuran pemusatan dikelompokkan berdasarkan bentuk yang sama. Dari setiap bentuk alasan yang sama, dipilih secara acak satu orang partisipan untuk diwawancarai secara wawancara klinis. Wawancara klinis (clinical interview) dilakukan karena metode ini dapat 
secara efektif memunculkan, mengklarifikasi dan memahami cara berpikir partisipan (Groth et al., 2016; Heng \& Sudarshan, 2013).

Ada sebanyak 16 orang partisipan yang terlibat dalam wawancara. Pada partisipan wawancara klinis disajikan jawaban asli mereka atas permasalahan yang diberikan. Dalam wawancara klinis ini, partisipan diminta untuk menjelaskan strategi dan pemikiran matematis (ways of thinking) mereka ketika menyelesaikan permasalahan ukuran pemusatan yang diberikan. Interviewer tidak mencoba untuk memvalidasi jawaban partisipan atau berusaha mengarahkan pemikiran mereka pada cara berpikir tertentu. Selama wawancara dilakukan, ada dua tujuan utama yaitu menguji mengenai cara berpikir dan cara memahami yang diperoleh dari analisis awal atas permasalahan yang mereka kerjakan. Kedua, memperoleh informasi tambahan mengenai cara berpikir dan cara memahami mereka akan ukuran pemusatan. Untuk itu, beberapa partisipan diberikan permasalahan tambahan ketika wawancara berlangsung. Semua wawancara direkam dan ditranskrip.

\section{Hasil Penelitian}

Dari 177 calon guru matematika, hanya 24 orang $(13,6 \%)$ yang bisa memilih ukuran pemusatan yang tepat. Calon guru matematika tepat memilih median atau modus pada permasalahan pertama dan memilih ukuran pemusatan dengan alasan yang tepat pada permasalahan kedua (dengan alasan yang tepat). Untuk melihat kesalahan dan kesulitan yang dihadapi, analisis cara berpikir dilakukan. Analisis cara berpikir dilakukan pada kedua respon, baik yang benar maupun yang salah.

Dari alasan yang diberikan saat menyelesaikan permasalahan maupun ketika wawancara, ada dua cara berpikir yang digunakan dapat memilih ukuran pemusatan. Kedua cara berpikir tersebut terlihat pada tabel 1 .

Tabel 1. Jenis respon partisipan

\begin{tabular}{|c|c|c|}
\hline No & Jenis Respon & Frekuensi \\
\hline 1 & Menyadari variansi data dan mempertimbangkannya & $24(13,6 \%)$ \\
\hline & a. Menggunakan Median & $17(9,6 \%)$ \\
\hline & b. Menggunakan Modus & $7(4 \%)$ \\
\hline 2 & Menyadari variansi data tetapi mengabaikannya & $153(84,4 \%)$ \\
\hline
\end{tabular}




\section{Menyadari variansi data dan mempertimbangkannya}

Tabel 1 menunjukkan $13,6 \%$ calon guru matematika menyadari variansi data akan mempengaruhi ketepatan ukuran pemusatan yang akan digunakan. Kesadaran ini terlihat dari respon calon guru matematika pada permasalahan pertama (lihat gambar 2).

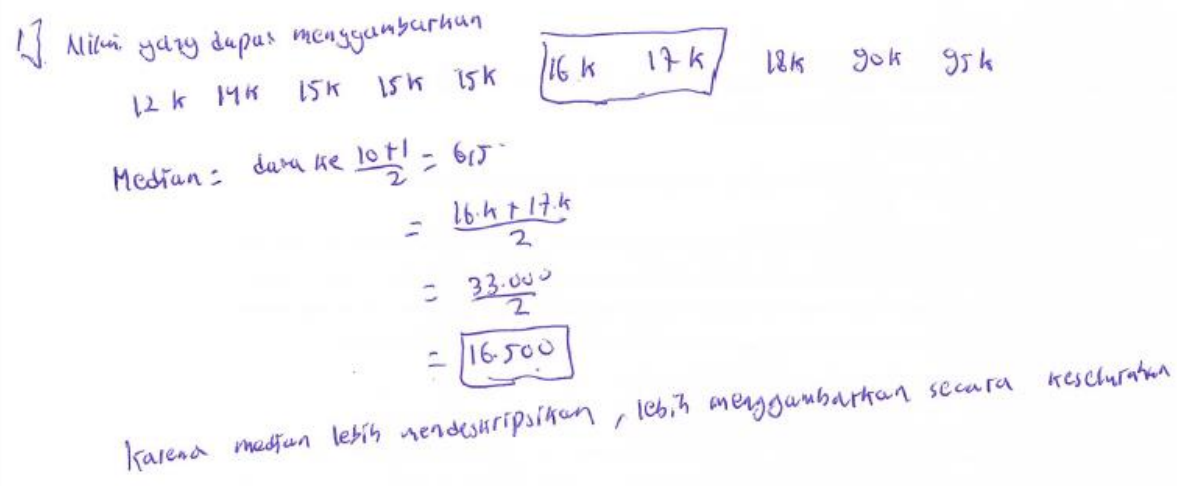

Gambar 2. Jawaban CGM-1 atas permasalahan pertama

Calon guru matematika mempertimbangkan adanya nilai ekstrem pada data. Oleh karena itu calon guru matematika memilih menggunakan median dibanding rata-rata. Alasannya karena nilai rata-rata tidak cukup merepresentasikan data. Hasil wawancara berikut menguatkan temuan tersebut.

Peneliti: Oke kita mulai nomer 1 Fan. Nah, saya tertarik bagaimana kamu menjawab nomor 1. Soalnya tentang gaji yah? Kenapa kamu menjawab nomor 1 dengan menggunakan median.

CGM-1: Karena dari data ini, gajinya itu bervariasi dan jarak-jaraknya, apa, ada yang sangat kecil dan sangat besar. Jadi, apa sih ini, gaji karywan ini semua tidka setara. Maksudnya ada data yang selisihnya sangat jauh gitu. Kita lihata ada gaji karyawan hanya 15k, sementara data ke-10 itu 95k. Kan rentangnya sangat besar. Kan biasanya kalau kita buat mean, tapi karena ini, apa ya? Aduh? Apa sih? [partisipan lupa mengenai suatu istilah yang ingin disebutkannya]

Peneliti: Selisihnya?

CGM-1: Iya selisihnya sangat besar semuanya dan bervariasi juga gitu, nah makanya saya buatnya median pak. Median itu kan yang ditengah. Misalnya kalo di kehidupan nyatanya. Misalnya se-perusahaan tertentu ada satu orang yang gajinya, misalnya ada guru gaji mereka 5 juta, tapi ada pengusaha yang kayak banget yang gajinya 1 milyar. Masa kita langsung cari mean dan samakan semua? Nanti kan bakalan besar semua kan gajinya.

Peneliti: Jadi kalau dicari mean apa dampaknya pada data itu?

CGM-1: Kalau dicari mean nanti saya melihat gaji karyawan itu [mean] tidak merepresentasikan secara keseluruhan.

Peneliti: Oh, kalau median yang ketemu 16,5 ya? Apakah representatif?

CGM-1: Nah kan kalo mediannya kan 16,5. Menurut saya banyak data yang cukup terepresentasikannya, kan dari 10 orang yang mendekati 16,5 ada 8. 
Dari wawancara di atas, terlihat pemilihan median dibanding rata-rata karena faktor variansi data. Menurut calon guru matematika, nilai rata-rata akan memiliki deviasi yang besar dari setiap datanya. Dengan demikian, nilai tersebut tidak cukup dapat mewakili semua data. Median setidaknya, menurut calon guru, cukup merepresentasikan data karena dari 10 ada 8 data yang dekat (deviasinya kecil) dengan nilai median 16,5. Sebaliknya, nilai rata-rata memiliki deviasi yang besar dari semua data.

Cara berpikir yang sama digunakan oleh calon guru matematika dalam menjawab permasalahan kedua. Pada permasalahan kedua, semua ukuran pemusatan cocok digunakan karena variansi data yang tidak begitu besar. Dari 9,6\% yang menjawab menggunakan median pada permasalahan pertama terdapat 6\% (satu orang) yang menggunakan median pada permasalahan kedua, 94\% menggunakan rata-rata dan tidak ada yang menggunakan modus. Sementara dari $4 \%$ yang menjawab dengan modus pada permasalahan pertama, terdapat $71 \%$ menggunakan rata-rata dalam menyelesaikan permasalahan kedua, 29\% nya menggunakan median dan tidak ada yang menggunakan modus. Artinya, tidak ada calon guru matematika yang menggunakan modus dalam menyelesaikan permasalahan kedua. Hal ini dikarenakan pertimbangan bahwa nilai modus memiliki variansi yang lebih tinggi dibanding rata-rata dan median. Hal itu terlihat dari wawancara di bawah ini.

Peneliti: Tetapi kalau nomor 3 kenapa kamu pilih menggunakan mean dibanding median dan modus?

CGM-2: Nomor 3 kenapa saya pilih mean ya sama seperti yang tadi pak, kalo yang pertama kan selisihya itu ada yang jauh banget, jadi yang kecil sama besarnya rentangya sangat besar. Sedagkan yang nomer 3 ini saya pilih mean karena nilai mereka itu bisa dikatakan standart defiasinya kecil gitu pak. Jadinya saya ambil mean karena itu udah cukup merepresentasikan seluruh data.

Peneliti: Oke berarti, karena kamu menggunakan 2 ukaran pemusatan yang berbeda ya, menurut kamu apa dasar kita memilih ukuran pemusatan median, modus, atau mean?

CGM-2: Bergantung dari datanya itu sendiri.

Wawancara di atas menunjukkan pemilihan ukuran pemusatan yang tepat ditentukan atas pertimbangan bentuk data itu sendiri, yaitu variansi-nya. Kesadaran dan pemahaman variansi data membuat calon guru matematika tersebut dapat memilih jenis ukuran pemusatan yang tepat.

Selain menggunakan median, ada juga calon guru matematika yang menggunakan ukuran pemusatan jenis modus (lihat gambar 3). Modus dipilih karena , menurut calon guru matematika, rata-rata tidak cocok digunakan untuk data tersebut. Sama seperti yang 
menggunakan median, calon guru matematika yang menggunakan modus juga melihat nilai modus memiliki deviasi yang kecil dari data.

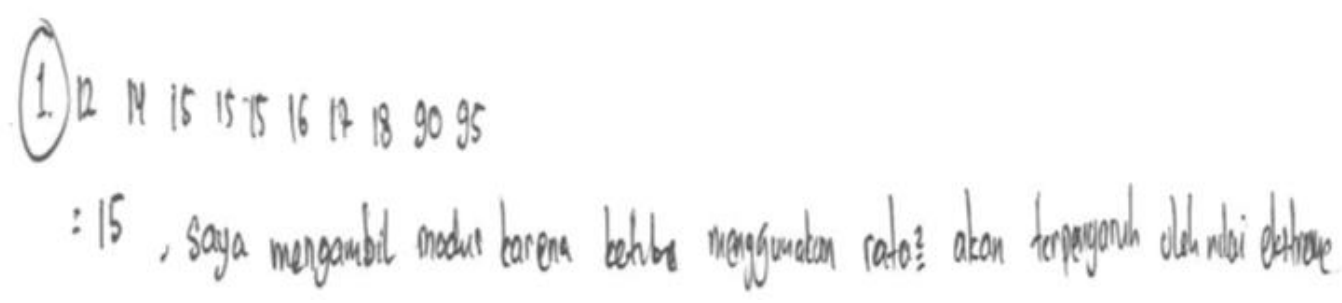

Gambar 3. Jawaban CGM-2 atas permasalahan pertama

\section{Menyadari variansi data tetapi mengabaikannya}

Dari tabel 1 terlihat sebanyak 84,4\% calon guru matematika menggunakan rata-rata dalam menyelesaikan permasalahan pertama (lihat Gambar 4). Pemilihan rata-rata kurang tepat dalam menyelesaikan permasalahan pertama. Rata-rata tidak tepat karena tidak handal terhadap adanya nilai pencilan, yaitu nilai 90 dan 95 .

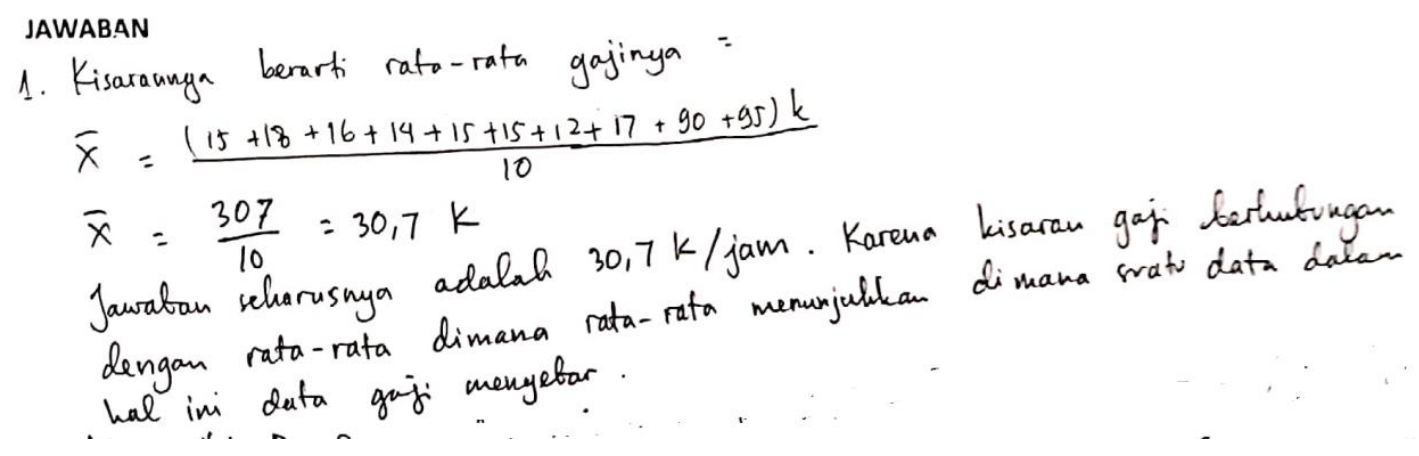

Gambar 4. Jawaban CGM-3 atas permasalahan pertama

Menurut calon guru matematika, kisaran suatu data berarti merujuk pada rata-rata. Kisaran berarti nilai yang mewakili data. Suatu nilai mewakili, menurut calon guru matematika, jika proses perolehannya melibatkan semua data melalui operasi perhitungan aritmatik. Hal ini diterlihat pada wawancara berikut.

Peneliti: Nomor 1 kamu menggunakan mean. Tadi kamu bilang merepresentasikan semua data dengan menggunakan mean?

CGM-3: Semua permasalahan diselesaikan dengan menggunakan mean

Peneliti: Coba kalau kita ambil mean-nya. Berapa nilai mean-nya? 16+18+16+14+ $15+15+12+70+90+95$ bagi 10

CGM-3: Ada yang salah kita pak

Peneliti: Oh ada yang salah ya? Coba-coba. $15+18+16+14+15+15+12+17+90+95$, benar ini udah 10.

CGM-3: 30,7

Peneliti: 30,7 kan, nah kita dapat 30,7. Kira-kira menurut kamu merepresentasikan data ini gak? Kalau mean, kenapa dia merepresentasikan data ini?

CGM-3: Kalau, kalau aku mikirnya sih pak, dia melibatkan data 
Peneliti: Melibatkan semua data ya. Kalau kita bilang, wah gaji mereka 30,7. Kira-kira akan mewakili semua data ini gak?

CGM-3: Gak sih pak, ini, ini yang paling jomplang kan pak

Peneliti: Iya ini kan jauh kesini [nilai terrendah] dan kesini juga jauh [nilai tertinggi]

CGM-3: Kalau dikatakan mewakili sih, mewakili semua data pak karena nilai ini kan hasil dari perhitungan semua data, mean-nya. Tapi, tapi memang perbedaannya sangat jauh gitu, dari 1-9 itu. Kalau mewakili, menurutku mewakili dari nilai semua data juga.

Peneliti: Kenapa mewakili? Bukankah kalau misalnya nih, kamu gak tahu data sesungguhnya. kalau disebutkan nilainya sekitar 30,7, yang dipikirkan oleh orang lain, datanya akan berada dimana? Berapa-berapa saja nilai-nya?

CGM-3: Sekitar 30-an.

Peneliti: Sekitar 30-an kan. Padahal ini [data] jauh-jauh semua dari nilai 30.

CGM-3: Tapi kan memang datanya kan itu pak. Tingkat perbedaannya gitu, ada pencilannya

Peneliti: Oke gitu pak.

CGM-3: Karena dua data ini. Yang bagian ini [12k-18k] masih lebih dekat tetapi ada pencilan mungkin ada pengaruhnya

Peneliti: Jadi, kamu tetap menyadari ada pencilan ini ya? Tapi, kenapa kamu tetap meyakini mean mewakili?

CGM-3: Karna melibatkan semua data

Wawancara di atas menunjukkan pemahaman calon guru matematika tentang nilai representasi suatu data. Suatu nilai dikatakan representataif jika diperoleh dengan melibatkan semua data dalam perhitungan. Tingkat keterpusatan data malah terabaikan karena pemahaman ini. Buktinya, mahasiswa tidak lagi mempertimbangkan apakah nilai rata-rata $(30,7)$ dekat (memiliki deviasi kecil) dari semua data. Jika diperhatikan lebih jauh, calon guru matematika sebenarnya menyadari adanya nilai pencilan dan pengaruhnya. Namun hal ini diabaikan karena nilai yang diperoleh sudah melibatkan semua data dalam operasi perhitungan. Selain itu, pengabaikan faktor variansi juga didasarkan pada faktor frekuensi data. Dibandingkan jumlah total, frekuensi nilai pencilan tidak signifikan (hanya dua dari sepuluh). Oleh karena itu, menurut calon guru matematika, nilai pencilan tidak signifikan. Cara berpikir seperti ini mengabaikan faktor variansi. Padahal, variansi tidak hanya ditentukan oleh berapa banyak nilai pencilan tetapi juga berapa besar nilai pencilan-nya.

Bentuk lain dari respon calon guru matematika adalah menggunakan rata-rata dengan modifikasi data. Ada dua bentuk modifikasi data yang dilakukan oleh calon guru matematika. Pertama, data dipisahkan menjadi dua bagian. Satu bagian terdiri dari data $12 \mathrm{k}-18 \mathrm{k}$ (12k, $14 \mathrm{k}, 15 \mathrm{k}, 15 \mathrm{k}, 15 \mathrm{k}, 16 \mathrm{k}, 17 \mathrm{k}, 18 \mathrm{k})$, bagian lain 90k-95k (90k, 95k) seperti yang terlihat pada gambar 5. Lalu dari kedua bagian ini, dicari masing-masing dicari nilai rata-rata-nya. Hal ini mengakibatkan adanya dua nilai rata-rata. Kedua nilai ini menjadi lebih memusat pada data yang diwakilinya dibanding tanpa modifikasi. 


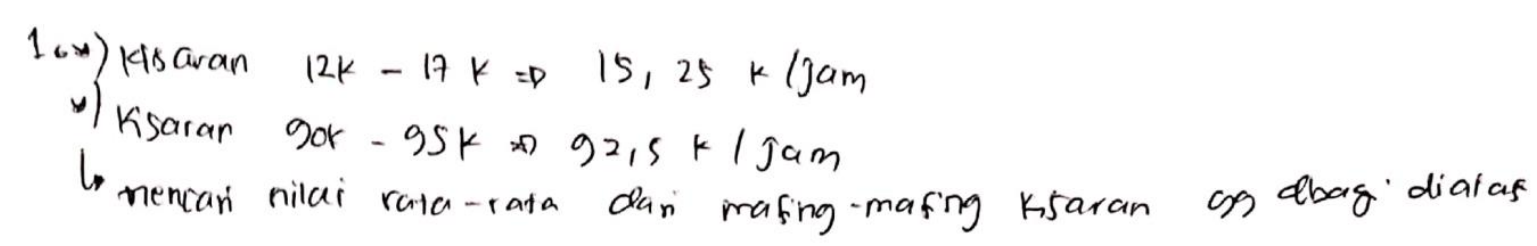

Gambar 5. Modifikasi bentuk pertama dan terjemahannya

Kedua, modifikasi dilakukan dengan menghilangkan nilai pencilan pada data yaitu nilai 90k dan 95k. Dengan demikian frekuensi data menjadi 12k, 14k, 15k, 15k, 15k, 16k, 17k, 18k. Kemudian nilai rata-rata ditentukan dari data baru tersebut. Deviasi setiap data dari rata-rata menjadi kecil atau keterpusatannya besar dibanding jika nilai pencilan diikutkan (lihat gambar $6)$.

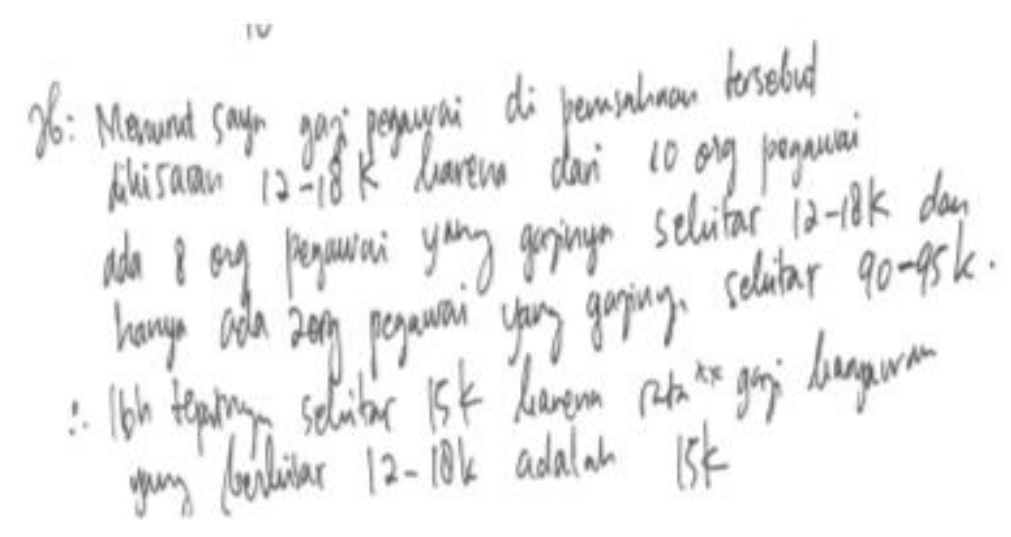

Gambar 6. Modifikasi bentuk kedua

Modifikasi data dilakukan karena calon guru matematika menyadari bahwa rata-rata sangat sensitif terhadap nilai pencilan (perhatikan wawancara di bawah ini). Oleh karena itu, data dimodifikasi agar rata-rata cocok digunakan. Artinya, calon guru matematika malah berorientasi pada rata-rata bukan pada data. Implikasinya, bukannya memilih ukuran pemusatan yang cocok sesuai dengan konteks data, calon guru matematika malahan mencocokkan data pada ukuran pemusatan tertentu. Hal ini juga menunjukkan pengabaian faktor variansi dalam menentukan ukuran pemusatan.

Peneliti: Oke, bagaimana kamu mengerjakannya?

CGM-4: Jadi nomer 1 itu saya bagi dua. Kan ada 10 orang kan. Nah ada 8 orang itu yang gajinya kan 12, about 12 sampai 17. Nah, saya cari mean dari kisaran 1217k itu. Nah, terus 2 orang yang sisanya yang dapat gaji 90-95 itu saya cari lagi mean-nya.

Peneliti: Kenapa kamu bagi dua? Dikelompokin jadi dua kenapa?

CGM-4: Karena dari gaji itu tuh terlihat berbeda. Dari gaji kisaran gaji 1-8 itu, kayak mendekati gitu kan pak. Sedangkan 9 dan 10 itu beda gitu, jauh beda. Jadinya saya bagi dua kisarannya. 
Peneliti: Oh, oke-oke. Tapi kan kalo diminta kalo satu nilai, ini kan jadi dua nilai. Kalo satu nilai menurut kamu memang akan pengaruh dengan karena dia jomplang tadi? Kenapa tidak diambil satu nilai, satu nilai mean?

CGM-4: Ya gitu saya mikirnya. Karena biar ga terlalu jauh aja gitu pak.

Peneliti: Terlalu jauh? Kalau satu nilai emang nanti jadi gimana? Kalau satu aja rataratanya.

CGM-4: Satu aja?

Peneliti: Iya, ini kan 2 rata-rata nih ya? Kalo satu aja menurut kamu? Kenapa ga satu kamu buat?

CGM-4: Kayak gitu pak, pemikirannya kayak gitu.

Peneliti: Oh berarti karena dua tadi itu ya? Karena jomplang itu ya?

Partisipan 4: Iya.

Calon guru matematika yang menjawab seperti di atas, juga menggunakan cara berpikir yang sama dalam menjawab permasalahan kedua. Yaitu cara berpikir yang tidak mempertimbangkan atau mengabaikan faktor variansi data. Sebagian besar menggunakan rata-rata dalam menyelesaikan permasalahan kedua, hanya ada tujuh orang yang menjawab dengan menggunakan median dan modus. Alasan yang menggunakan rata-rata adalah karena rata-rata diperoleh dengan melibatkan semua data.

Sementara yang menggunakan median beralasan karena yang mewakili harus nilai yang di tengah-tengah. Sementara yang menggunakan modus karena yang paling banyak muncul adalah konsistensi hasil belajar. Artinya, meskipun pemilihan rata-rata, median atau modus tepat untuk permasalahan kedua, namun alasan yang diberikan menunjukkan calon guru matematika tidak mempertimbangkan faktor variansi data dalam memilihnya.

Hasil penelitian yang telah dipaparkan di atas memberikan jawaban atas pertanyaan penelitian yang telah diajukan. Calon guru matematika tidak tepat memilih ukuran pemusatan yang sesuai karena mengabaikan faktor variansi dalam proses pemilihan ukuran pemusatan dalam menghadapi permasalahan.

\section{Pembahasan}

Hasil penelitian ini menunjukkan pemilihan ukuran pemusatan tidak boleh dilepaskan dari variansi. Pengabaian variansi dalam proses pemilihan dan penggunaan ukuran pemusatan akan menghasilkan ketidaktepatan. Implikasinya, saat menggunakan ukuran pemusatan, kita tidak boleh hanya fokus pada dirinya. Berikut akan dipaparkan alasan terlalu fokus pada ukuran pemusatan sembari mengabaikan variansi merupakan penyebab ketidakmampuan memilih ukuran pemusatan yang tepat.

Pertama, natur dari statistika dan penalaran statistik. Statistika adalah ilmu yang dikembangkan atau mendapat wawasan dari data (Dierdorp et al., 2014). Artinya 
penyelidikan statistika bergantung pada data dan didasarkan pada konteks (Kuntze et al., 2017). Implikasinya dalam pemilihan ukuran pemusatan, prosesnya harus dimulai dari konteks data. Dalam penyelidikan data kita harus mengajukan pertanyaan: berdasarkan bentuk data ini, ukuran pemusatan mana yang tepat merepresentasikannya? Bukan sebaliknya, bagaimana data ini diperlakukan agar cocok dengan ukuran pemusatan tertentu? Dengan demikian, pemilihan ukuran pemusatan harus lebih bersifat gaining from data dibanding applied for data. Misalnya, pada kasus CGM-1 yang dipaparkan pada bagian hasil di atas. Proses berpikirnya dimulai dari eksplorasi akan data. Hal pertama yang dilakukan dalam memilih ukuran pemusatan adalah dengan mengamati sifat dan karateristik data. Hasil pengamatan ini, pada permasalahan pertama, menunjukkan data memiliki nilai pencilan.

Pengamatan dan pertimbangan adanya nilai pencilan ini merupakan bentuk pertimbangan akan variansi data. Seseorang tidak mungkin mampu mengamati nilai pencilan jika hanya fokus pada ukuran pemusatan. Yang menarik, bukan pada apakah seseorang mengamati variansi (adanya nilai pencilan) atau tidak, tetapi apakah dia mengabaikannya atau mempertimbangkannya. Dengan proses ini, calon guru matematika mampu memilih ukuran pemusatan yang tepat sesuai dengan sifat dan karateristik datanya (contohnya CGM-1). Begitu juga ketika memilih ukuran pemusatan yang tepat pada permasalahan kedua. Meskipun jenis yang dipilih sama, calon guru matematika yang mempertimbangkan faktor variansi tahu alasan pemilihan, dibanding yang tidak mempertimbangkan.

Sebaliknya, calon guru matematika yang tidak mampu memilih ukuran pemusatan yang tepat, menunjukkan bahwa pemahaman statistiknya lebih bersifat aplikasi untuk data (applied for data). Aplikasi pada data berarti cara berpikir-nya bergerak dari: konsep matematis ukuran pemusatan diaplikasikan untuk data. Buktinya, bukannya mengganti atau mencari alternatif selain rata-rata, calon guru matematika malah memodifikasi (menghilangkan sifat, karateristik dan bagian dari data) sehingga cocok dengan penggunaan rata-rata. Hal ini tidak sesuai dengan natur statistika itu sendiri. Dengan demikian, terlihat bahwa fokus pada ukuran pemusatan akan membawa cara berpikir dan penalaran akan ukuran pemusatan bersifat aplikasi untuk data.

Kedua, natur dari distribusi dan pusat distribusi data. Para statistikawan melihat ukuran pemusatan sebagai a signal amidst noise (tanda di tengah kebisingan) (Konold \& Higgins, 2011). Bahkan, bukan hanya untuk memahami distribusi, ide bahwa data sebagai a mixture of signal and noise (campuran antara tanda dan kebisingan) adalah konsep fundamental dalam statistika (Konold \& Higgins, 2011; Konold et al., 2015; Konold \& Pollatsek, 2002). Artinya, ide tentang ukuran pemusatan data tidak bisa dilepaskan dari ide tentang variansi (Hjalmarson 
et al., 2011). Data merupakan kesatuan antara ukuran pemusatan (signal) dan variansi (noise). Implikasinya, fokus pada ukuran pemusatan akan membawa pemaknaan yang salah mengenai ukuran pemusatan itu sendiri (Koparan, 2015). Pandangan ini memberikan justifikasi atas hasil penelitian di atas. Calon guru matematika yang terlalu fokus atau tidak mempertimbangkan variansi malah tidak mampu memilih ukuran pemusatan yang tepat. Nilai ukuran pemusatan yang dipilih malah tidak mewakili (signal) dari data tersebut. Hal ini karena variansi memiliki tingkat pengaruh yang berbeda untuk setiap jenis ukuran pemusatan.

Kedua penjelasan di atas menunjukkan bahwa fokus pada ukuran pemusatan dengan mengabaikan variansi merupakan penyebab ketidakmampuan calon guru matematika memilih ukuran pemusatan yang tepat. Temuan ini memberikan implikasi dalam pembelajaran. Pendekatan pembelajaran harus di ubah. Untuk mendorong pemahaman yang kuat, ukuran pemusatan harus diperkenalkan secara bersamaan dengan variansi. Hal ini sesuai dengan penelitian Holt \& Scariano (2009). Menurut mereka, dalam pembelajaran untuk mendorong pemahaman akan ukuran pemusatan situasi didaktis yang cocok adalah dengan memberikan permasalahan dimana siswa harus menentukan dan merefleksikan ukuran pemusatan mana yang tepat digunakan untuk suatu data tertentu. Implikasinya, jika dapat digunakan dalam proses pembelajaran maka dapat juga digunakan dalam proses investigasi pemahaman (hasil pembelajaran). Hal ini sesuai dengan penelitian yang dilakukan oleh Zawojewski \& Shaughnessy (2016). Penelitian ini mengungkapkan penyelidikan mengenai pemahaman akan ukuran pemusatan dengan menggunakan permasalahan yang mendorong pemilihan ukuran pemusatan yang tepat.

Diskusi hasil penelitian di atas harus dipahami dengan mengingat beberapa keterbatasan. Pertama, bentuk instrumen berupa permasalahan yang mendorong partisipan memilih ukuran pemusatan yang tepat bukanlah satu-satunya cara untuk melihat pemahaman. Bentuk permasalahan lain seperti permasalahan yang mengukur pemahaman prosedural dan konseptual dan membandingkan dua distribusi data dapat juga digunakan untuk hubungan antara center dan variansi. Untuk itu perlu penelitian yang lebih luas agar dapat mencakup semuanya. Kedua, penelitian ini belum menganalisis pemahaman mengenai karateristik masing-masing ukuran pemusatan. Terutama mengenai pemahaman sifat-sifat masing-masing ukuran pusat dan hubungannya dengan kemampuan memilih ukuran pusat yang tepat. Untuk itu perlu penelitian lebih lanjut untuk melihat kemungkinan hubungan pemahaman akan karateristik masing-masing ukuran pemusatan dengan kemampuan memilih ukuran pemusatan yang tepat. 


\section{Simpulan}

Calon guru matematika tidak dapat memilih ukuran pemustan yang tepat karena terlalu fokus pada ukuran pemusatan, sembari mengabaikan ukuran variansi. Untuk mampu memilih ukuran pemusatan yang tepat ketika menghadapi permasalahan, variansi harus dipertimbangkan secara bersamaan. Hal ini sesuai dengan natur statistik itu sendiri dan secara khusus natur data. Hasil penelitian kami memberikan dasar pada suatu desain didaktis. Untuk mendorong pemahaman yang kuat dan komprehensif, ukuran pemusatan harus diperkenalkan secara bersamaan.

Penelitian ini masih terbatas dalam bentuk permasalahan (soal tes) yang digunakan. Perlu penelitian lebih lanjut dengan melibatkan bentuk permasalahan (soal tes) yang lebih luas. Khususnya mengenai pemahaman atas properties masing-masing ukuran pemusatan dan hubungannya dengan kemampuan memilih ukuran pemusatan yang tepat.

\section{Ucapan Terima Kasih}

Penelitian di sini didukung oleh Universitas Pelita Harapan, melalui dana penelitian internal dengan nomor P-035-FIP/I/2019. Isi penelitian ini adalah tanggung jawab penulis dan tidak mewakili pandangan Institusi.

\section{Referensi}

Amaro, J. A. O., \& Sánchez, E. A. (2019). Students Reasoning About Variation in Risk Context. In G. Burrill \& D. Ben-Zvi Editors (Eds.), Topics and Trends in Current Statistics Education Research ICME-13 Monographs (pp. 51-69). Cham: Springer. https://doi.org/10.1007/978-3-030-03472-6_3.

Amiruzzaman, M. (2016). Exploring preservice teachers' understanding of measures of central tendency. Disertasi tidak dipublikasikan, Ohio, Kent State University.

Bakker, A. (2003). The early history of average values and implications for education. Journal of Statistics Education, 11(1), 1-18. https://doi.org/10.1080/10691898.2003.11910694.

Ben-Zvi, D., \& Aridor-Berger, K. (2015). Children's wonder how to wander between data and context. In S. J. Cho (Ed.), The Proceedings of the 12th International Congress on Mathematical Education: Intellectual and attitudinal challenges (pp. 25-36). Seoul: Springer Open. https://doi.org/10.1007/978-3-319-23470-0_3.

Ben-Zvi, D., Aridor, K., Makar, K., \& Bakker, A. (2012). Students' emergent articulations of uncertainty while making informal statistical inferences. ZDM - International Journal on Mathematics Education, 44(7), 913-925. https://doi.org/10.1007/s11858-012-04203.

Blanco, T. G., \& Chamberlin, S. A. (2019). Pre-service teacher statistical misconceptions during teacher preparation program. Mathematics Enthusiast, 16(1-3), 461-484. https://scholarworks.umt.edu/cgi/viewcontent.cgi?article=1469\&context=tme.

Braham, H. M., \& Ben-Zvi, D. (2017). Students' emergent articulations of statistical models and modeling in making informal statistical inferences. Statistics Education Research 
Journal, 16(2), 116-143. https://doi.org/10.1007/s11858-012-0420-3.

Cohen, L., Manion, L., \& Morrison, K. (2018). Research Methods in Education (8th ed.). New York: Routledge. https://doi.org/10.4324/9781315456539.

Dierdorp, A., Bakker, A., van Maanen, J. A., \& Eijkelhof, H. M. (2014). Meaningful statistics in professional practices as a bridge between mathematics and science: an evaluation of a design research project. International Journal of STEM Education, 1(1), 1-15. https://doi.org/10.1186/s40594-014-0009-1.

English, L. D., \& Watson, J. M. (2015). Exploring variation in measurement as a foundation for statistical thinking in the elementary school. International Journal of STEM Education, 2(1), 1-20. https://doi.org/10.1186/s40594-015-0016-X.

Groth, R. E., \& Bergner, J. A. (2006). Preservice elementary teachers' conceptual and procedural knowledge of mean, median, and mode. Mathematical Thinking and Learning, 8(1), 37-63. https://doi.org/10.1207/s15327833mt10801_3.

Groth, R. E., Bergner, J. A., \& Burgess, C. R. (2016). An Exploration of Prospective Teachers' Learning of Clinical Interview Techniques. Mathematics Teacher Education and Development, 18(2), 48-71. https://files.eric.ed.gov/fulltext/EJ1113963.pdf.

Heng, M. A., \& Sudarshan, A. (2013). "Bigger number means you plus!"-Teachers learning to use clinical interviews to understand students' mathematical thinking. Educational Studies in Mathematics, 83(3), 471-485. https://doi.org/10.1007/s10649-013-9469-3.

Hjalmarson, M. A., Moore, T. J., \& Delmas, R. (2011). Statistical analysis when the data is an image: Eliciting student thinking about sampling and variability. Statistics Education Research Journal, 10(1), 15-34. https://iaseweb.org/documents/SERJ/SERJ10(1)_Hjalmarson.pdf.

Holt, M. M., \& Scariano, S. M. (2009). Mean, median and mode from a decision perspective. Journal of Statistics Education, 17(3), 1-16. https://doi.org/10.1080/10691898.2009.11889533.

Ismail, Z., \& Chan, S. W. (2015). Malaysian students' misconceptions about measures of central tendency: an error analysis. AIP Conference Proceedings, 1643(1), 93-100. https://doi.org/10.1063/1.4907430.

Kemendikbud. (2016). Peraturan Menteri Pendidikan Dan Kebudayaan Nomor 21 Tahun 2016 Tentang Standar Isi Pendidikan Dasar Dan Menengah. Jakarta: Kemendikbud.

Konold, C, \& Higgins, T. (2011). Reasoning about Data. In W. G. Kilpatrick, M. D. E., \& R. Schifter (Eds.), A research companion to principles and standards for school mathematics (pp. 193-215). Reston: National Council of Teachers of Mathematics.

Konold, Clifford, Higgins, T., Russell, S. J., \& Khalil, K. (2015). Data seen through different lenses. Educational Studies in Mathematics, 88(3), 305-325. https://doi.org/10.1007/s10649-013-9529-8.

Konold, Clifford, \& Pollatsek, A. (2002). Data analysis as the search for signals in noisy processes. Journal for Research in Mathematics Education, 33(4), 259-289. https://doi.org/10.2307/749741.

Koparan, T. (2015). Difficulties in learning and teaching statistics: teacher views. International Journal of Mathematical Education in Science and Technology, 46(1), 94-104. https://doi.org/10.1080/0020739X.2014.941425.

Kuntze, S., Aizikovitsh-Udi, E., \& Clarke, D. (2017). Hybrid task design: connecting learning opportunities related to critical thinking and statistical thinking. ZDM - Mathematics Education, 49(6), 923-935. https://doi.org/10.1007/s11858-017-0874-4.

Manikandan, S. (2011). Measures of central tendency: the mean. Journal of Pharmacology and Pharmacotherapeutics, 2(2), 140-142. https://doi.org/10.4103/0976-500X.81920.

Morris, B. J., \& Masnick, A. M. (2015). Comparing data sets: implicit summaries of the statistical properties of number sets. Cognitive Science, 39(1), 156-170. 
https://doi.org/10.1111/cogs.12141.

OECD. (2014). PISA 2012 results: What students know and can do - student performance in mathematics, reading and science (Vol. 1). Paris: OECD Publishing. https://doi.org/10.1787/9789264201118-en.

Zawojewski, J. S., \& Shaughnessy, J. M. (2016). Mean and median: are they really so easy? Mathematics Teaching in the Middle School, 5(7), 436-440. https://doi.org/10.5951/MTMS.5.7.0436. 